\title{
A review of the Himalayan genus Trypheridium Brancucci (Coleoptera: Cantharidae: Chauliognathinae) with description of a new species
}

\author{
R.M. ZUBAIR ${ }^{\circledR 1}$, Amir MAQBOOL ${ }^{\circledR 2, *}$, Aijaz Ahmad WACHKOO ${ }^{\circledR 3}{ }^{3}$ \& Gabriel BIFFI ${ }^{(04}$ \\ ${ }^{1}$ Entomology Section, Department of Zoology, University of Kashmir, \\ Hazratbal Srinagar, Jammu and Kashmir 190006, India. \\ ${ }^{2}$ Department of Higher Education, Government College for Women, M.A. Road, \\ Cluster University of Srinagar, Jammu and Kashmir 190003, India. \\ ${ }^{3}$ Department of Zoology, Government Degree College, Shopian, Jammu and Kashmir 192303, India. \\ ${ }^{4}$ Museu de Zoologia da Universidade de São Paulo, Av. Nazaré, 481 - Ipiranga, \\ 04263-000 São Paulo, SP, Brazil. \\ ${ }^{*}$ Corresponding author: amaqbool@uok.edu.in \\ 1Email: zarsaki55@gmail.com \\ ${ }^{3}$ Email: aijaz_shoorida@yahoo.co.in \\ [4Email: biffigabriel@gmail.com \\ ${ }^{1}$ urn:1sid:zoobank.org:author:A8FF6E93-B7E0-427D-AB6C-3DA55CE5157A
${ }^{2}$ urn:Isid:zoobank.org:author:E133BF0C-6419-4BBC-808A-89057A9A822B
${ }^{3}$ urn:1sid:zoobank.org:author:6F19EB1F-5DDC-4722-BBD3-F75C29F901D9
${ }^{4}$ urn:1sid:zoobank.org:author:1F5A526D-13F0-4A33-AA33-D9B7497E5689
}

Abstract. The genus Trypheridium Brancucci, 1985 is endemic to the Hindu Kush Himalayan Region, and is currently known from a single species, T. nuristanicum (Wittmer, 1956). Here, the genus is reviewed, T. nuristanicum nom. emend. is re-described and T. kashmiricum sp. nov. is described from Kashmir Himalayan Region of India. Descriptions, diagnoses, high quality images, distribution maps and identification keys are presented. The morphology and distribution of Trypheridium are discussed and compared with those of the closely related genus Trypherus LeConte, 1851.

Keywords. Ichthyurini, Himalaya, Kashmir, morphology, taxonomy.

Zubair R.M., Maqbool A., Wachkoo A.A. \& Biffi G. 2021. A review of the Himalayan genus Trypheridium Brancucci (Coleoptera: Cantharidae: Chauliognathinae) with description of a new species. European Journal of Taxonomy 764: 18-36. https://doi.org/10.5852/ejt.2021.764.1467

\section{Introduction}

The genus Trypheridium Brancucci, 1985 was originally described from the Hindu Kush Himalayan Region, for a single species Trypherus nuristanicus Wittmer, 1956 based on distinct morphological characters and disjunct distribution. Superficially, Trypheridium resembles Trypherus LeConte, 1851 but can be distinguished from the latter by 'aberrant' sexual characters and unmodified mid legs (Brancucci 1985a). 
Trypheridium seems to be restricted to the Hindu Kush Himalayan Region whereas Trypherus is widespread across the eastern Palaearctic and the Nearctic, with a greater diversity in Taiwan (Brancucci 1985b; Pelletier \& Hébert 2014; Satô et al. 2014). The Hindu Kush is an 800 km long mountain range that stretches through Afghanistan, from its centre to Northern Pakistan and into Tajikistan, and is home to four global biodiversity hotspots, and hundreds of mountain peaks over $6000 \mathrm{~m}$ (Chettri et al. 2008; Searle 2013). The range forms the western section of the Hindu Kush Himalayan Region and is the westernmost extension of the Pamir Mountains, the Karakoram and the Himalayas.

In this study we revise the taxonomy of the genus Trypheridium and describe a new species T. kashmiricum sp. nov. from the Kashmir Himalayan Region of India and re-describe T. nuristanicum nom. emend. All descriptions include diagnoses, taxonomic discussions, and high quality stacked images. In addition, we provide an illustrated identification key to species, as well as maps showing the known distribution ranges.

\section{Material and methods}

Specimens of T. kashmiricum sp. nov. were collected at Waripora, Tangmarg area $\left(34^{\circ} 05^{\prime} 30^{\prime \prime} \mathrm{N}\right.$, 74³3'31" E, 1639 m a.s.1.) of Baramulla District, in Kashmir Valley, the Palaearctic portion of India, located in the northwestern part of the Indian subcontinent between $33^{\circ} 22^{\prime}$ and $34^{\circ} 50^{\prime} \mathrm{N}$ latitudes and $73^{\circ} 55^{\prime}$ and $73^{\circ} 33^{\prime}$ E longitudes (Maqbool et al. 2018; Wachkoo et al. 2018). The specimens were hand collected from the leaves of walnut trees (Juglans regia L.), which were heavily infested with aphids (Fig. 1). The alcohol (70\% ethanol) preserved specimens were air dried and card mounted for taxonomic studies.

The map of the sampling site was created by using the administrative-boundary vector map of India at district level (Survey of India) at a scale of 1:1000000. Geographical coordinates of the sampling

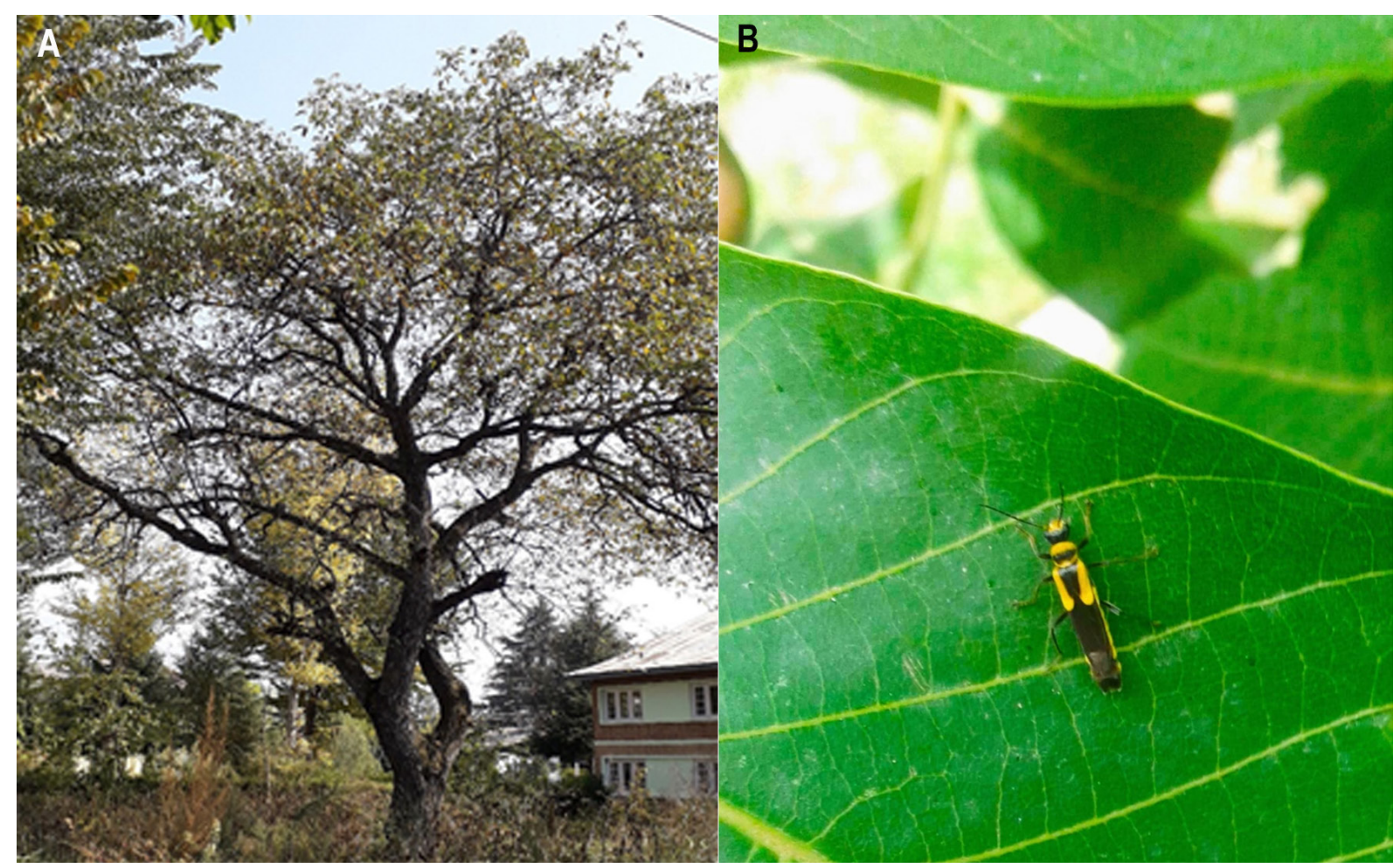

Fig. 1. Trypheridium kashmiricum sp. nov., ․ A. Habitat (Juglans regia L.). B. On a walnut leaf. 
site were imported to mapping software and the sampling site was plotted. The ArcMap module of the ArcGIS package ver. 10.1 (www.esri.com) was used to prepare the map of Kashmir Valley showing the sampling site. The species distribution map was prepared using Google maps.

The specimens were observed under a Magnus MS 24 stereoscopic binocular microscope. Card point mounted specimens were placed inside a light-box using cool daylight LED lamps $(3 \mathrm{~W})$ and images were captured using a DSLR camera (Nikon D5300) with a macro lens (Tokina $100 \mathrm{~mm}$ f2.8). Multiple images were generated using an auto stacking-rail (Stackrail rs90) and merged using Combine ZP software. The final images were cleaned with Adobe Photoshop CS4. The abdomens of specimens were detached with forceps and treated with $20-30 \% \mathrm{KOH}$ for about 48 hours. After appropriate transparency was achieved, abdomens were cleaned in $75 \%$ ethanol and placed on cavity slides with glycerin. Abdominal sternites and genitalia were dissected and mounted for microphotography. For brightfield microscopy, prepared slides were placed on a stage prepared from cardboard and provided with an LED lamp (3W) to produce the transmission light beam. For darkfield microscopy a darkfield illumination filter was used to illuminate unstained specimens. Microphotographs were captured with a digital mirrorless camera (Nikon Z50) attached with infinity-corrected microscope objectives (Lomo $3.7 \times$ and Nikon CFI Plan Achromat 10X).

The terminology used in the descriptions follows that of Brancucci $(1980,1985 b)$, except for the tergite IX and X that replaces the terms paraproct and proctiger respectively, and a new orientation of the aedeagus. The correct orientation of the aedeagus of the Chauliognathinae is still contentious, as two opposite terminologies are used for each of the lineages (cf. Biffi 2020). Brancucci (1985b) attempted to correct the general hypothesis of homology for the aedeagus of the Chauliognathinae proposed by Magis \& Wittmer (1974). However, the terminology used by Brancucci (1985a, 1985b) is actually based on an aedeagus disposed in a dorsal position, rather than ventral as he stated. We therefore consider the aedeagus of species of Trypheridium as having two elongate outgrowths: right paramere (rather than "left paramere" sensu Brancucci), and a prolongation of the tegmen to the left (rather than "right prolongation of tegmen" sensu Brancucci). The left paramere ("right paramere" sensu Brancucci) is here considered to be missing. The descriptions and diagnoses below were adapted to accordingly follow this present orientation of the aedeagus.

\section{Repositories}

KUIC $=$ Kashmir University Insect Collection, Jammu and Kashmir, India

NHMB = Naturhistorisches Museum Basel, Basel, Switzerland

\section{Results}

Class Insecta Linnaeus, 1758

Order Coleoptera Linnaeus, 1758

Superfamily Elateroidea Leach, 1815

Family Cantharidae Imhoff, 1856

Subfamily Chauliognathinae LeConte, 1861

Tribe Ichthyurini Champion, 1915

Genus Trypheridium Brancucci, 1985

Figs 2-7

Trypheridium Brancucci, 1985a: 245.

Trypheridium - Kazantsev 2004: 30 (catalogue); 2012: 403 (catalogue). - Kazantsev \& Brancucci 2007: 297 (catalogue). 


\section{Type species}

Trypherus nuristanicus Wittmer, 1956, by original designation.

\section{Diagnosis}

Trypheridium is similar to Trypherus, and distinguished by sexual characters: tergite IX with dorsal and ventral blades ("lames tergales et sternales") very long and asymmetrical (Figs 3A-D, 6E-F); aedeagus without left paramere, median lobe membranous (Figs 3F-J, 6G-I), with orifice apically (not preapically as in Trypherus); female with sternite VII remarkably broad, partly or completely concealing most of sternite VIII (Figs 4G-H, 7B); bursa copulatrix elongate, with two tubular spermathecae and one accessory gland connecting the bursa in its postero-dorsal part (Figs 5F, 7D).

\section{Re-description (Figs 6-7)}

\section{Coloration}

General coloration pale to sulphur yellow with dark brown to black patches; head yellow anteriorly at frons and clypeus and infuscate at vertex and occipital region; antennae dark brown to black, the three or four basal antennomeres yellow; pronotum with a transversal black band at posterior half; elytra with dark brown to black triangular patches, from the base of elytra (not reaching the humeri) and extending posteriorly; wings dark brown; legs dark brown or black, usually fore and mid legs light brown with dark spots; abdominal tergites and ventrites black in the centre and yellow at the margins. Coloration in females usually darker.

\section{Male}

HABITUS. Length 6.5-8.5 mm.

HEAD. Head (including the eyes) wider than pronotum; vertex flat, frons concave between the eyes, occipital region convex, sides rounded and regularly narrowing behind the eyes. Eyes large, oblong, bulging, longer than wide, broadly separated. Fronto-clypeal suture distinct laterally, indistinct in the middle; anterior margin of clypeus slightly sinuous, nearly straight; labrum membranous. Mandibles arcuate, apex acute, blunt, retinaculum in the same plan as incisor, apex rounded, with a small supplementary tooth at the base of retinaculum. Maxillary palp with fourth palpomere elongate, narrowing apicad. Antennae not juxtaposed, separated by at least the width of antennal sockets; with 11 antennomeres, filiform, without modifications; antennomere I slender, without swellings.

PRonotum. Transverse, wider than long, convex; anterior margin broadly arched, lateral margins nearly straight, slightly narrowing posteriorly; posterior margin projected posteriorly; anterior and posterior angles rounded, barely distinct. Elytra short, 1.2-1.4 times longer than combined width, slightly narrowed laterally, suture dehiscent posteriorly, apex rounded.

WINGs. With reduced venation, radial cell $2 \mathrm{R}_{1}$ closed; vein $\mathrm{r}-\mathrm{m}$ barely visible, vein $\mathrm{Cu}$ straight, vein $\mathrm{Mr}$ fading; transversal vein cu-a absent; $\mathrm{Rr}$ extends beyond the joining of vein $\mathrm{r}$; vein $\mathrm{A}_{\mathrm{x} 2}$ well visible, not joining $\mathrm{Ax}_{1+2}$ and ending near the joining of vein $\mathrm{A}$ and $\mathrm{Ax}_{1+2}$.

LEGS. Slender, without swellings, teeth or remarkable modifications; apex of fore tibia with a pair of tiny spurs; all tarsal claws with broad internal teeth.

AвDOMEN. Weakly sclerotised; tergites with a pair of small glandular pores on the distal corners; pores of tergite VIII in the apex of projections. Tergite VIII long and broad, with distal corners projected posteriorly, distal margin arcuate, concave. Tergite IX (paraproct) strongly modified in a capsule with a pair of long and asymmetrical lamellar projections directed ventrally; left blade ("lame sternale" of 
Brancucci) longer, flattened; right blade ("lame tergale" of Brancucci) shorter, more strongly curved ventrally. Tergite X (proctiger) divided posteriorly into two projecting lobes. Sternite VIII (ventrite VII) asymmetrical, distal margin sinuous and deeply notched, sides projected posteriorly. Sternite IX concealed underneath sternite VIII, elongate, lamellar, weakly sclerotised.

AEDEAGus. Elongated and weakly sclerotised; left paramere absent, right paramere and the prolongation of tegmen elongate and directed posteriorly; left prolongation of tegmen broad and lamellar, margins sinuous. Median lobe membranous, short, not twisted, with its broad opening located apically.

\section{Female}

Similar to males, except for eyes slightly smaller and more separated; sternite VII long and broad, mostly concealing sternite VIII, distal margin with elongate lobes projecting posteriorly. Sternite VIII membranous, broadly rounded, distal margin with a broad rounded lobe projecting posteriorly; coxites small, not fused medially, anterior arms very long and slender, apparently fused with valvifers, styles elongate, digitiform. Genitalia membranous, consisting of a long and broad vagina; oviduct anteriorly in the vagina; bursa copulatrix elongate, wrinkled, spiralling; spermatheca formed by two tubular projections; accessory gland large, connected by a long winding duct to the postero-dorsal part of bursa copulatrix.

\section{Distribution}

Trypheridium seems to be endemic to the Hindu Kush Himalayan Region. The only species described prior to this work has been reported from Tajikistan, Afghanistan (Nuristan) and Pakistan (Fig. 8A). Herein, we report a new species of this genus from India (Fig. 8B).

\section{Key to the species of Trypheridium Brancucci, 1985}

1. Males: right blade of tergite IX bifurcating terminally into two unequal lobes (Fig. 3A-D); tergite $\mathrm{X}$ divided into two very long asymmetrical projections (Fig. 3B). Females: sternite VII long, mostly concealing sternite VIII, projecting beyond the tip of abdomen, distal margin with three projections (Fig. 4G-H).

Trypheridium kashmiricum sp. nov.

- Males: right blade of tergite IX undivided (Fig. 6E-F); tergite X divided into two short asymmetrical lobes (Fig. 6D, F). Females: sternite VII shorter, partly exposing sternite VIII, distal margin with two projections (Fig. 7B-C) Trypheridium nuristanicum (Wittmer, 1956)

Trypheridium kashmiricum sp. nov. urn:1sid:zoobank.org:act:DF4DAB14-589A-4B50-A37C-9EFC31438D86

Figs 2-5

\section{Diagnosis}

This species resembles T. nuristanicum in general morphology and coloration, but differs in the structure of male and female terminal abdominal segments. In males, the right blade of tergite IX bifurcates terminally into two unequal lobes and tergite $\mathrm{X}$ divides into two very long asymmetrical projections. Sternite VII in females projects beyond the tip of abdomen, mostly concealing sternite VIII, and forms three projections apically.

\section{Etymology}

The species epithet is in reference to the type locality. 


\section{Type material}

\section{Holotype}

INDIA - O'; Jammu and Kashmir, Baramulla, Tangmarg; 3405'30" N, 74³3'31" E; 1639 m a.s.1.; 10 Aug. 2018; Zubair R.M. leg.; KUIC 0013.

\section{Paratypes}

INDIA 1 गे, 2 우; same collection data as for holotype; KUIC 0014 to KUIC 0016.

\section{Other material}

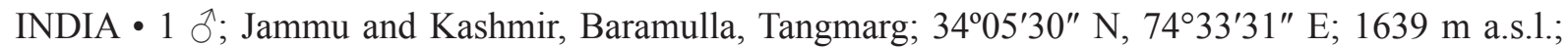
10 Aug. 2018; Zubair R.M. leg.; KUIC 0017.

\section{Description}

\section{Coloration}

Head black in vertex and occipital region, yellow in frons and clypeus. Antennae dark brown, except the three and part of fourth basal antennomeres and sometimes underside of latter, yellow; sometimes antennomeres II and III infuscate. Mandibles yellowish with dark-brown apex. Palpi light brown, infuscate at distal palpomeres. Pronotum partly translucent, yellow with transversal black band at posterior half, not reaching lateral and posterior pronotal margins. Elytra sulphur yellow with triangular dark brown patch from base of elytra extending posteriorly along suture up to about posterior third of elytra; integument shinning, covered with fine yellow pubescence. Wings, meso- and metaventrite dark brown to black. Legs: fore and mid coxae yellow, hind coxa partly yellow and partly brown; fore and mid femora yellowish (black in females) except having black patch towards dorsal apex; fore tibia and tarsus yellow; mid tibia testaceous brown and tarsus dark brown; hind legs completely dark brown except yellowish brown basal margin; darker specimens have legs more broadly infuscate. Abdominal ventrites and tergites dark brown to black at the centre and yellow at margins; last ventrites and tergites light to dark brown (especially in females).

\section{Male (Figs 2-3)}

HABitus. Length $7.8 \mathrm{~mm}$ in holotype (Fig. 2A-C), $7.6 \mathrm{~mm}$ in paratype.

HEAD. Head (including eyes) wider than pronotum (Fig. 2D-E), 1.3 times as wide as long (across middle of eyes); vertex flat, frons slightly concave between eyes, with pair of longitudinal furrows running between antennae sockets; area around antennal sockets depressed and with carinated margin, forming ridge between antennae that reaches up to vertex; integument smooth and lustrous, with very small punctures and densely covered with short and fine setae. Fronto-clypeal suture defined laterally, indistinct medially. Eyes large, bulging, longer than wide, glabrous; interocular space 1.6 times wider than widest width of eye. Antennae filiform (Fig. 2F), slender, 0.56 times body length, covered with short and fine setae; antennomere I 1.68 times length of II, 0.88 times length of antennomere III, 0.84 times length of antennomere IV, antennomeres IV-VI longest, subequal, latter decreasing apicad, XI pointed at apex.

Pronotum. Transverse (Fig. 2G) 1.3 times as wide as long, sides narrowed posteriorly, rounded, anterior margin arcuate, anterior angles rounded, not defined, posterior margin projected posteriorly, sinuous; disc slightly arched, integument partly translucent, smooth and lustrous, coarsely punctured and densely covered with fine pubescence. Scutellum with sides parallel, apex truncate. Scutellum trapezoidal, with pair of shallow and broad concavities anteriorly, posterior margin with rounded notch.

ELYTRA. Short, 0.28 times as long as body length, about 1.89 times length of pronotum, 1.2 times longer than width of both elytra; sides slightly narrowed at posterior third, sutures parallel anteriorly and 


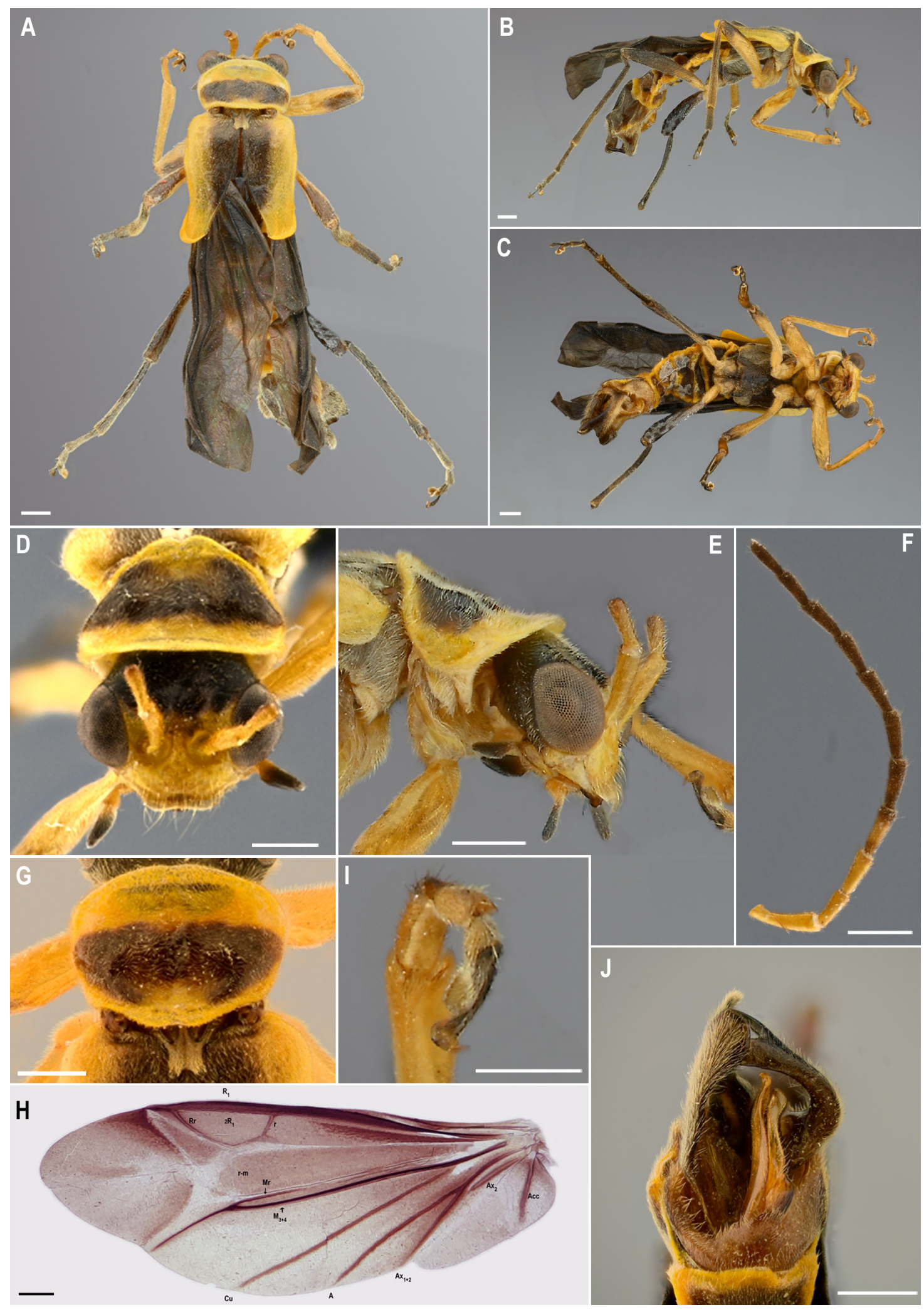

Fig. 2. Trypheridium kashmiricum sp. nov. $\oint^{\Uparrow}$, holotype (KUIC 0013). A. Habitus, dorsal view. B. Habitus, lateral view. C. Habitus, ventral view. D. Head, frontal view. E. Head, lateral view. F. Antenna. G. Pronotum. H. Hind wing. I. Apex of fore tibia showing a pair of tiny spurs. J. Terminal segments, ventral view. Scale bars: $0.5 \mathrm{~mm}$. 

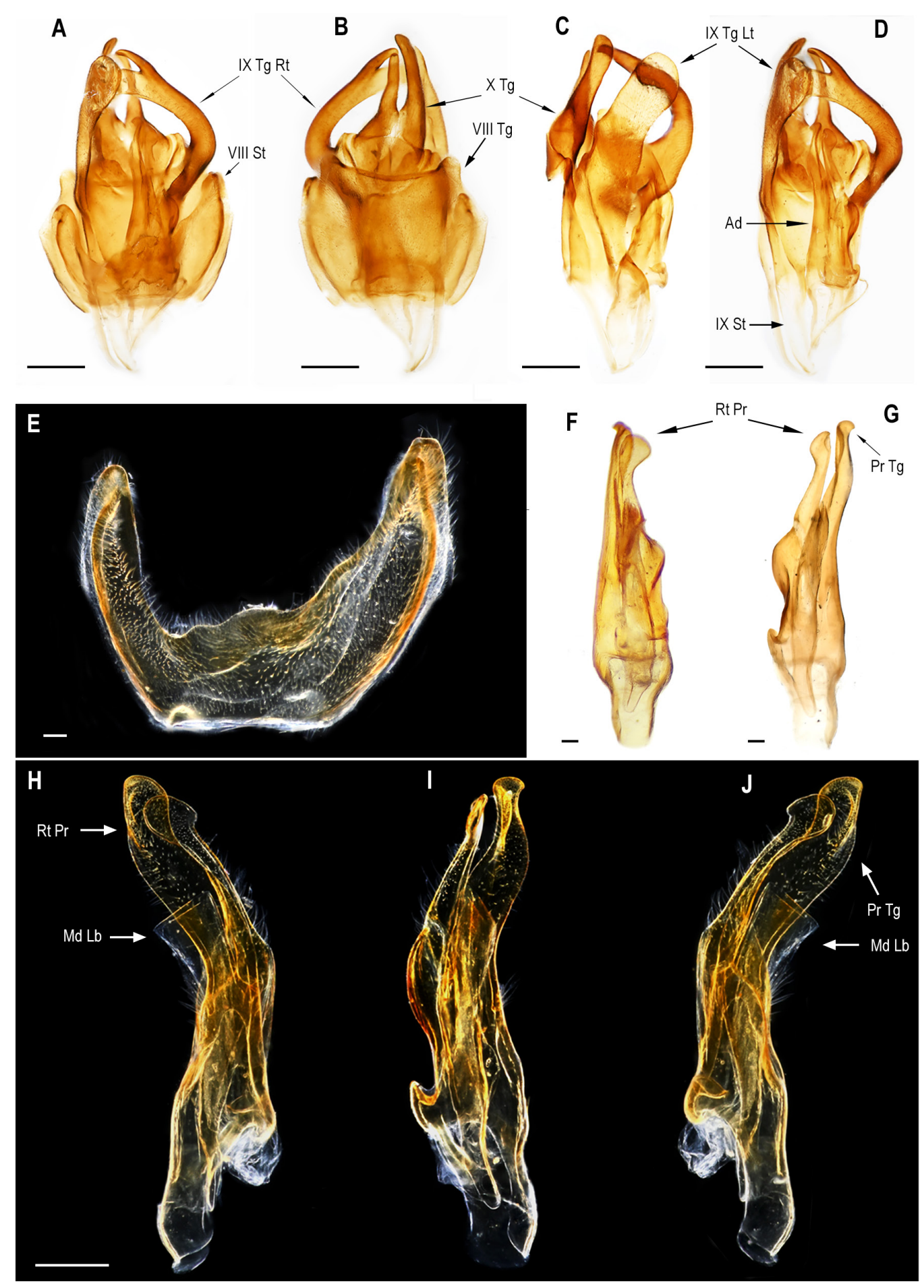

Fig 3. Micro images (brightfield and darkfield) of Trypheridium kashmiricum sp. nov. $\hat{\jmath}$, holotype (KUIC 0013), terminal segments genitalia. A. Ventral view. B. Dorsal view. C. Lateral view. D. Ventral view with IX sternite and tergite removed. E. IX ${ }^{\text {th }}$ sternite. F. Aedeagus in ventral view. G. Aedeagus in dorsal view. H. Aedeagus in lateral view, left side. I. Aedeagus in dorso-lateral view. J. Aedeagus in lateral view, right side. Abbreviations: VIII St=sternite VIII; VIII Tg=tergite VIII; IX St=sternite IX; IX Tg =tergite IX; IX Tg Lt=left blade of tergite IX; IX Tg Rt=right blade of tergite IX; X Tg=tergite $\mathrm{X} ; \mathrm{Ad}=$ aedeagus; $\mathrm{Md} \mathrm{Lb}=$ median lobe; $\operatorname{Pr} \mathrm{Tg}=$ prolongation of tegmen; $\mathrm{Rt} \operatorname{Pr}=$ right paramere. Scale bars: A-D, $\mathrm{H}-\mathrm{J}=0.5 \mathrm{~mm} ; \mathrm{E}-\mathrm{G}=0.1 \mathrm{~mm}$. 
dehiscent from posterior half, apex of each elytron rounded and flattened; integument slightly rugose, almost smooth, with fine punctures and densely covered with short and fine setae.

WINGS. With reduced venation (Fig. $2 \mathrm{H}$ ), radial cell $2 \mathrm{R}_{1}$ closed; vein $\mathrm{r}-\mathrm{m}$ barely visible, vein $\mathrm{Cu}$ straight; transversal vein cu-a absent; $\mathrm{Rr}$ extends beyond the joining of vein $\mathrm{r}$; vein $\mathrm{A}_{\mathrm{x} 2}$ well visible, not joining $\mathrm{Ax}_{1+2}$ and ending near the joining of vein $\mathrm{A}$ and $\mathrm{Ax}_{1+2}$.

LEGS. Slender, increasing in length from fore to hind, without strong modifications. Apex of fore tibia with a pair of very tiny spurs (Fig. 2I).

AвDOMEN. Weakly sclerotised; tergite VIII globose, longer and wider than preceding ones, distal margin arcuate, concave, posterior angles projected, with conspicuous glandular openings; tergite IX with two elongated, asymmetrical and protruding lamellae (blades) that converge towards the apex, giving it a shape of 'forceps' (Fig. 2J); right blade curves ventrally and bifurcates terminally into two unequal lobes (Fig. 3A); left blade broad, apex rounded (Fig. 3C), less sclerotised, almost parallel to abdominal axis; dorsally, tergite IX with pair of glandular openings in apex of short projections, lateral margins rounded, posterior margin slightly arcuate; tergite $\mathrm{X}$ large and produced into two unequal, asymmetrical, narrow and elongated lobes (Fig. 3B-C). Sternite VIII wider than long, 'U' shaped, asymmetrical, forming two narrow and very long asymmetrical lobes (Fig. 3E), sternite IX internalised, weakly sclerotised, elongate, flanking the aedeagus laterally to left inside abdomen.

Aedeagus. Elongated and weakly sclerotised (Fig. 3F-G); left paramere absent, right paramere and prolongation of tegmen directed posteriorly. Right paramere elongated (Fig. $3 \mathrm{H}$ ), ventral face with row of setae, apex flattened, forming rounded lobe; left prolongation of tegmen broad and lamellar (Fig. 3J), margins sinuous, apex rounded with tip pointing laterally. Median lobe membranous, short, not twisted, with its broad opening located apically.

Female (Fig. 4-5)

HABITUS. Length 7.4-7.6 mm $(\mathrm{n}=2)$ (Fig. 4A-C).

Similar to male, except for eyes slightly smaller (Fig. 4D-E), interocular distance across base of antennae 1.16 times wider than in male; elytra 0.32 times body length, 1.88 times the pronotum length; sternite VII variable (Fig. 4G-H), long and projecting posteriorly into 3 flattened lobes: 2 shorter pointed lobes laterally and medial lobe broad, parallel-sided, distal margin, with rounded notch (Fig. 5A); sometimes lateral lobes longer, almost as long as medial lobe, and distal margin of medial lobe truncate, not notched. Sternite VIII (Fig. 5C) almost completely concealed by sternite VII, membranous, broadly rounded, distal margin with broad rounded lobe projecting posteriorly; tergite VIII rounded on sides basally with wide and deep notch apically forming two apical lobes; coxites small (Fig. 5E), not fused medially, anterior arms very long and slender, apparently fused with valvifers, styles elongate, digitiform. Genitalia membranous (Fig. 5F); vagina long and broad; bursa copulatrix elongate, wrinkled, spiralling; spermatheca formed by two tubular projections; accessory gland large, connected by long winding duct to the postero-dorsal part of bursa copulatrix.

\section{Biological notes}

The specimens were collected on walnut tree leaves (Juglans regia L.) infested with walnut aphids, Chromaphis juglandicola (Kaltenbach, 1843) and Panaphis juglandis (Goeze, 1778).

\section{Distribution}

India (Baramulla, Kashmir) (Fig. 8A-B). 


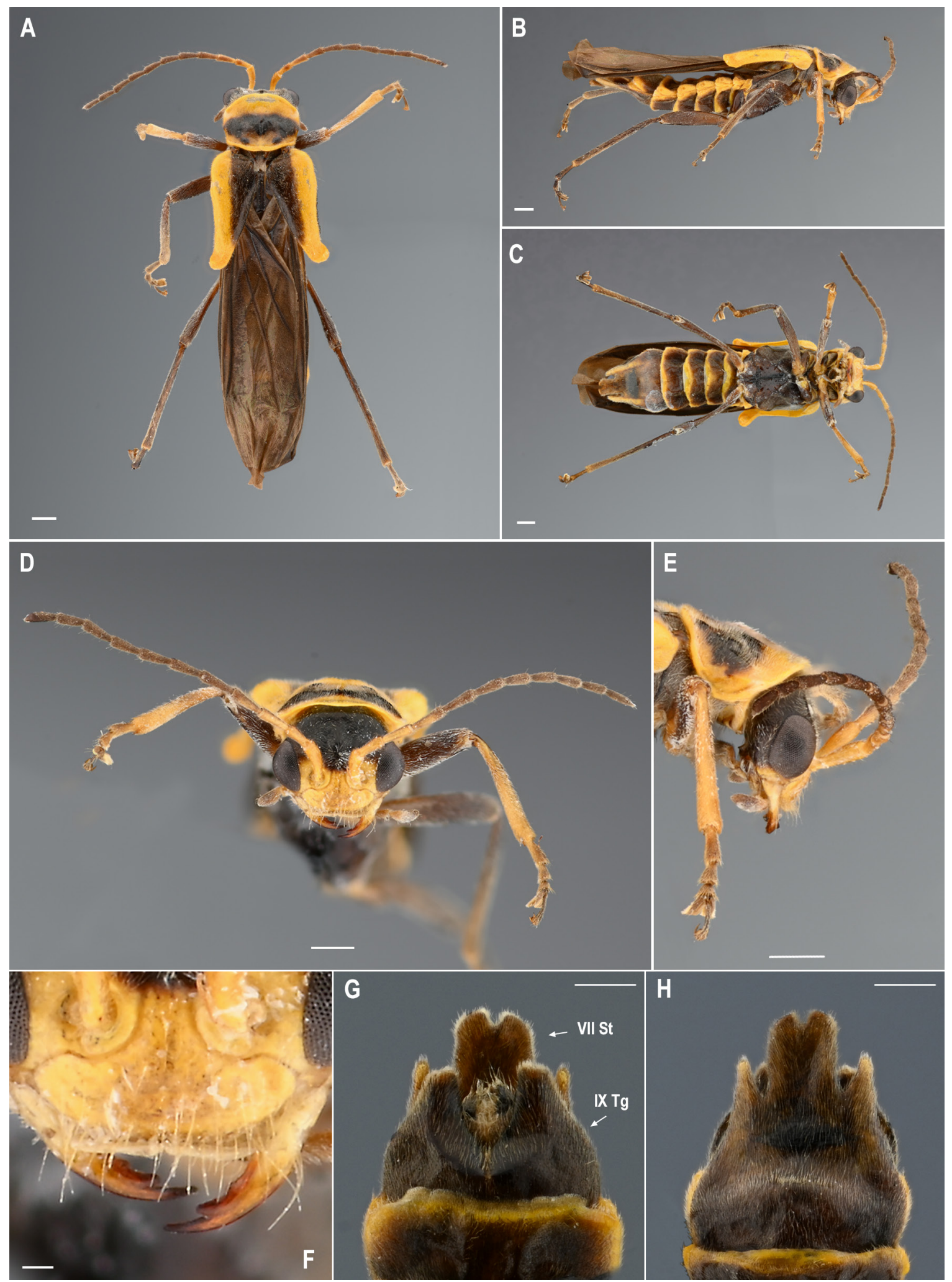

Fig. 4. Trypheridium kashmiricum sp. nov. ${ }_{+}$, paratype (KUIC 0015). A. Habitus, dorsal view. B. Habitus, lateral view. C. Habitus, ventral view. D. Head, front view. E. Head, lateral view. F. Mandibles. G. Terminal segments dorsal view. H. Terminal segments, ventral view. Abbreviations: VII St=sternite VII; IX Tg=tergite IX. Scale bars: A-E, G-H=0.5 mm; F=0.1 mm. 

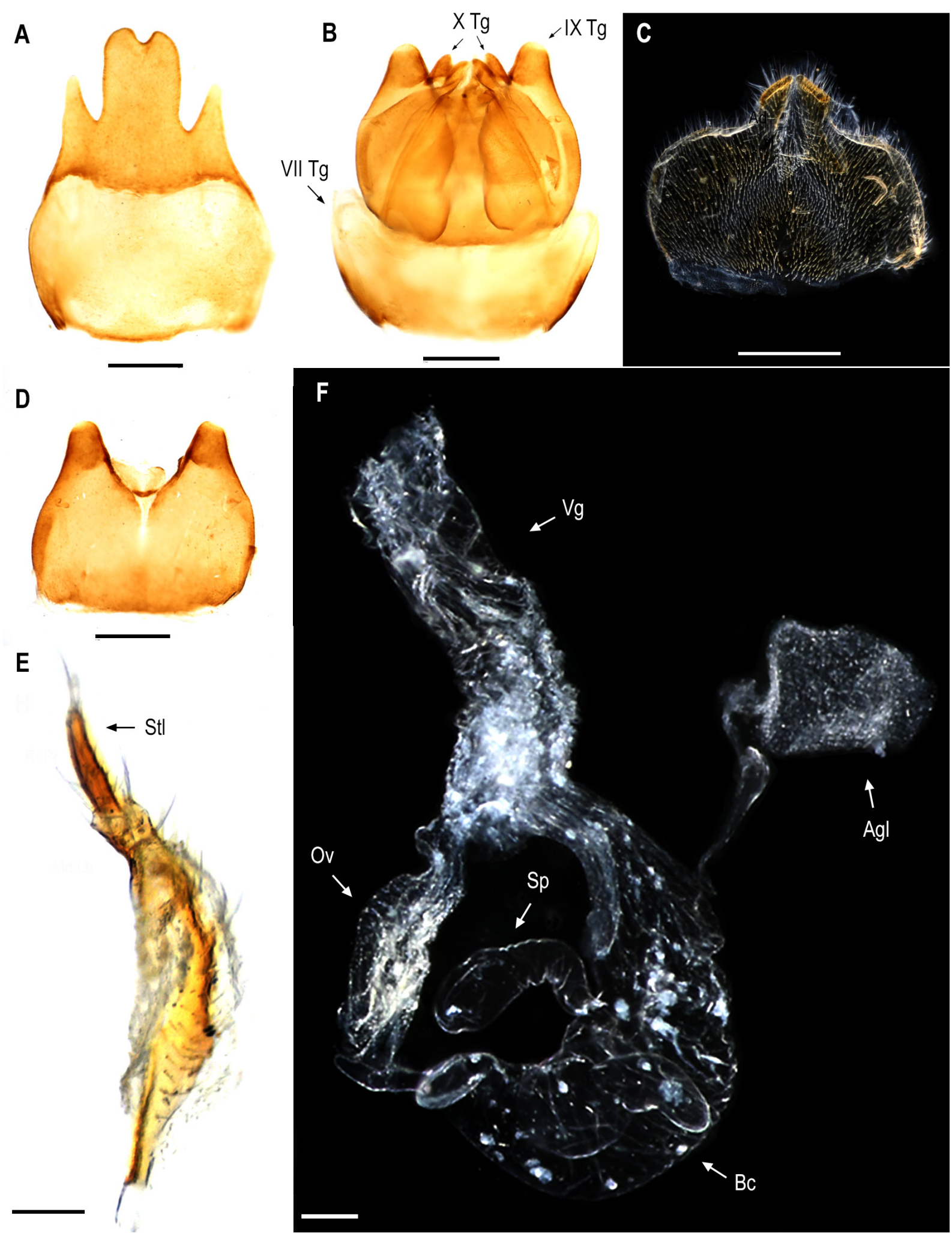

Fig. 5. Micro images (brightfield and darkfield) of Trypheridium kashmiricum sp. nov. + , paratype (KUIC 0015), terminal segments and genitalia. A. Sternite VII. B. Terminal segments (ventral view) with sternite VII removed. C. Sternite VIII. D. Tergite VIII. E. Coxite. F. Membranous genitalia. Abbreviations: VII Tg=tergite VII; IX Tg=tergite IX; X Tg=tergite X; $\mathrm{Agl}=$ accessory gland; $\mathrm{Bc}=$ bursa copulatrix; $\mathrm{Ov}=$ oviduct; $\mathrm{Sp}=$ spermatheca; $\mathrm{Stl}=$ style; $\mathrm{Vg}=$ vagina. Scale bars: $\mathrm{A}-\mathrm{D}=0.5 \mathrm{~mm} ; \mathrm{E}-\mathrm{F}=0.1 \mathrm{~mm}$. 
Trypheridium nuristanicum (Wittmer, 1956) nom. emend.

Figs 6-7

Trypherus nuristanicus Wittmer, 1956: 158.

Ichthyurus lopatini Medvedev, 1964: 44, fig. 1.

Ichthyurus lopatini - Wittmer 1972: 121 (synonym).

Trypherus nuristanicus - Magis \& Wittmer 1974: figs 7, 11 (morphology). — Delkeskamp 1977: 479 (catalogue). - Brancucci 1980: 257, fig. 219 (morphology).

Trypheridium nuristanicus - Brancucci 1985a: 246, figs 1-4 (re-description); 1985b: 296 (species list).

— Kazantsev 2004: 30 (catalogue); 2012: 403 (catalogue). — Kazantsev \& Brancucci 2007: 297

(catalogue).

\section{Diagnosis}

Trypheridium nuristanicum differs from T. kashmiricum sp. nov. in the structure of the male and female terminal abdominal segments. In males, the right blade of tergite IX is undivided terminally and tergite $\mathrm{X}$ is divided into two short asymmetrical lobes. Sternite VII in females is short, partly exposing sternite VIII, with 2 projections at the distal margin.

Material examined (from photographs)

Paratypes

AFGHANISTAN • 1 ठ̊; Nuristan, Baschgaltal; 1200 m a.s.1.; 15 Apr.1953; Wittmer W. leg.; [Klapperich J., Afghanistan exped.]; "Paratype; CANTHARIDAE, CANTH00014269, [QR Code label]"; NHMB •

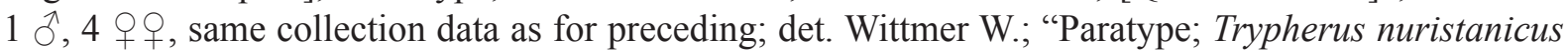
Wittm.; CANTH00013839; [QR Code label]"; NHMB • 1 đ; Nuristan, Baschgaltal; 1100 m a.s.l.; 15 Apr.1953; Wittmer W. leg.; "Klapperich J., Afghanistan exped.”; NHMB.

Re-description (partly adapted from Wittmer 1956 and Brancucci 1985a)

\section{Coloration}

Head black in the vertex and occipital region, yellow in the frons and clypeus. Antennae dark brown, except the three or four first antennomeres and sometimes the underside of the later, yellow. Palpi light brown, infuscate at distal palpomeres. Pronotum yellow with a transversal black band at posterior half, nearly reaching the lateral and posterior pronotal margins. Elytra sulphur yellow, sometimes lighter at the apex; a triangular dark brown patch from the base of elytra extending posteriorly along the suture up to about posterior third of elytra. Wings, meso- and metaventrite dark brown to black. Legs usually black; fore tibia and base of femur sometimes testaceous to light brown, fore femur rarely completely testaceous; bases of mid femur and tibia sometimes lighter. Abdominal ventrites and tergites dark brown to black at the centre and yellow at the margins; last ventrites and tergites mostly to completely yellow. Coloration in females, especially of the legs, usually a little darker.

Male (Fig. 6)

HaBitus. Length 6.5-8.5 mm (Fig. 6A).

HEAD. Head (including the eyes) wider than pronotum; vertex flat, frons slightly concave between eyes, with fine longitudinal furrow in middle, which ends in semicircular impression between antennae sockets; integument smooth and lustrous, with very small punctures and densely covered with short and fine setae. Eyes large, bulging; interocular space slightly wider than widest width of eye. Antennae filiform, slender, reaching apex of elytra posteriorly, covered with short and fine setae; antennomere I slender, II more than a third shorter than III, antennomeres IV and V subequal and following decreasing in length. 
Pronotum. Transverse (Fig. 6B) 1.1 times as wide as long, sides narrowed posteriorly, anterior margin regularly arched, anterior angles barely defined, posterior margin projected posteriorly, truncate at middle and concave laterally; disc slightly arched, integument smooth and lustrous, coarsely punctured and densely covered with fine pubescence. Scutellum with sides parallel, apex truncate.

A

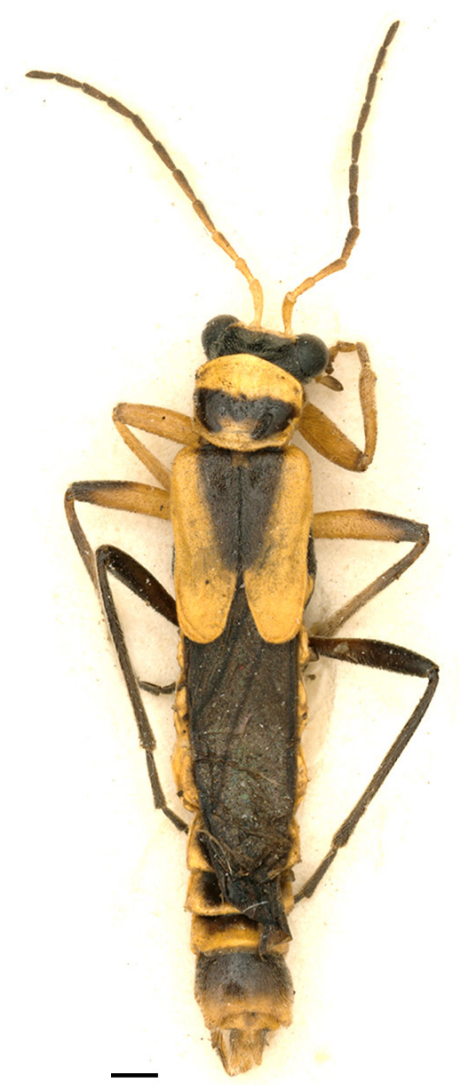

G

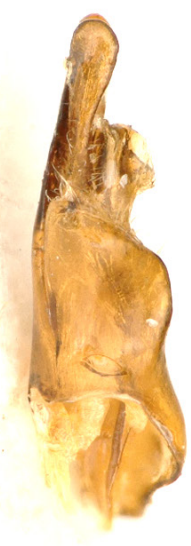

H

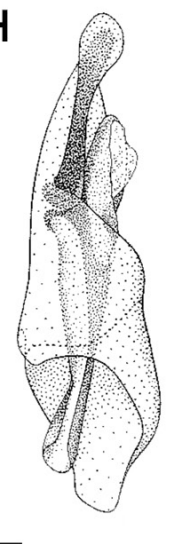

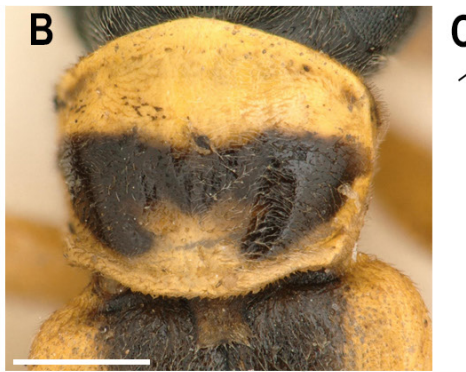
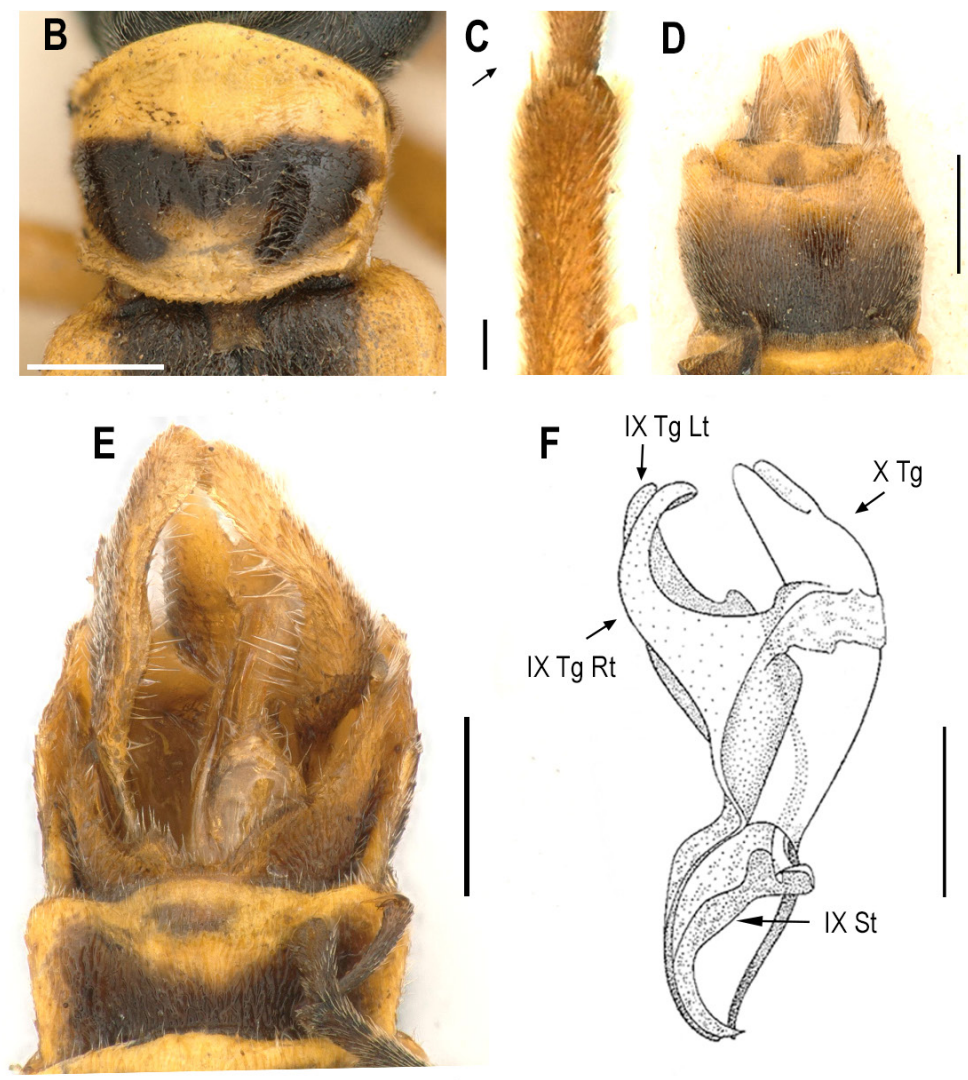

F
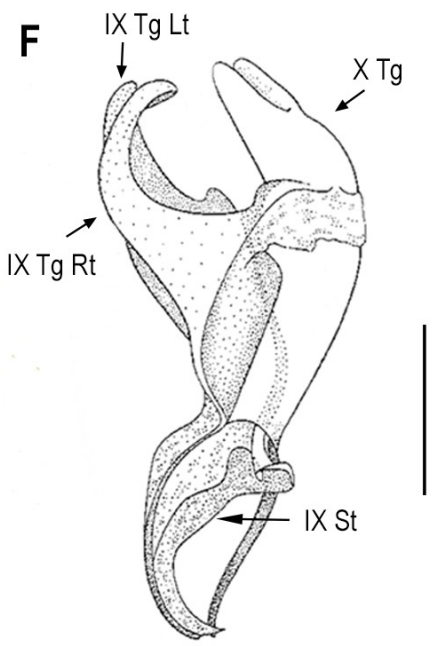
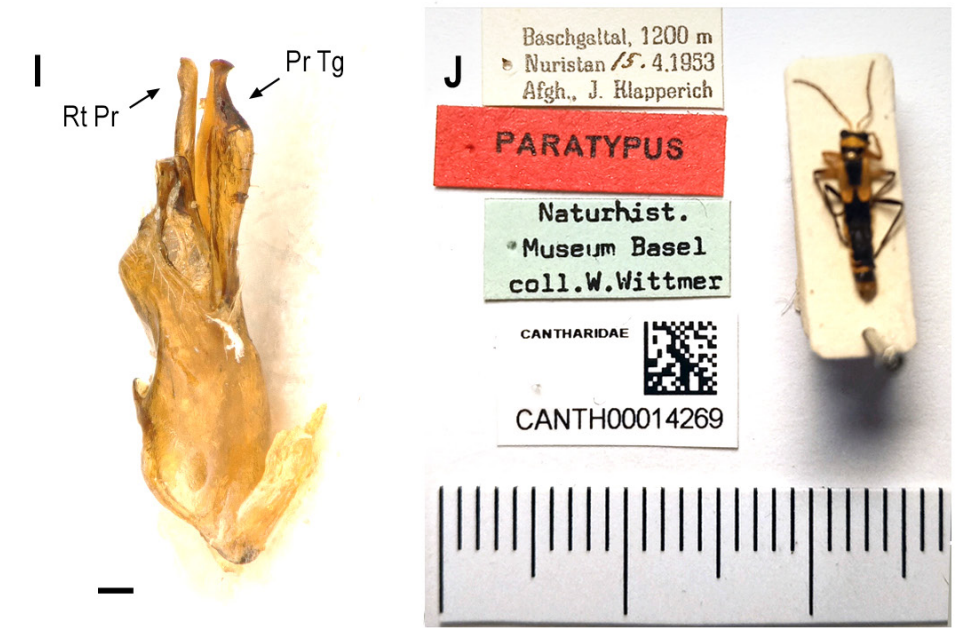

Fig. 6. Trypheridium nuristanicum (Wittmer, 1956) nom. emend., paratype, §ิ (CANTH00014269, NHMB). A. Dorsal habitus. B. Pronotum. C. Apex of fore tibia showing a pair of tiny spurs (arrow). D. Terminal segments, dorsal view. E. Terminal segments, ventral view. F. Terminal segments, lateral view. G-H. Aedeagus, lateral view. I. Aedeagus, ventral view. J. Paratype label. Abbreviations: IX $\mathrm{St}=$ sternite IX; IX Tg Lt=left blade of tergite IX; IX Tg Rt=right blade of tergite IX; X Tg=Tergite X; $\operatorname{Pr} \mathrm{Tg}=$ prolongation of tegmen; $\mathrm{Rt} \mathrm{Pr}=$ right paramere. Scale bars: A-B, D-F $=0.5 \mathrm{~mm} ; \mathrm{C}, \mathrm{G}-\mathrm{I}=0.1 \mathrm{~mm}$. Line drawings (F, H) adapted from Magis \& Wittmer (1974). 
ELYTRA. Short, 1.4 times longer than width of both elytra; sides slightly narrowed at posterior third, sutures parallel anteriorly and dehiscent from posterior third, apex of each elytron rounded and flattened; integument slightly rugose, almost smooth, with fine punctures and densely covered with short and fine setae.

LEGs. Slender, increasing in length from fore to hind, without strong modifications. Apex of fore tibia with pair of tiny spurs (Fig. 6C).

ABDOMEN. Weakly sclerotised; tergite VIII globose (Fig. 6D), longer and wider than preceding ones, distal margin arcuate, concave, posterior angles with conspicuous glandular openings; tergite IX modified into capsule with two elongate, asymmetrical and protruding lamellae (blades) that converge towards apex (Fig. 6E-F): left blade curved ventrally and posteriorly, long, flattened, weakly sclerotised, apex broadly rounded; right blade shorter, more strongly curved ventrally, apex rounded, undivided; tergite $\mathrm{X}$ strongly narrowed (Fig. 6F), longer than wide, split at base into two asymmetrical lobes projected posteriorly, one of lobes slightly shorter than other. Sternite VIII asymmetrical, distal margin deeply notched, sinuous, with sides projected posteriorly; sternite IX lamellar (Fig. 6F), weakly sclerotised, concealed underneath tergites VII and VIII.

A

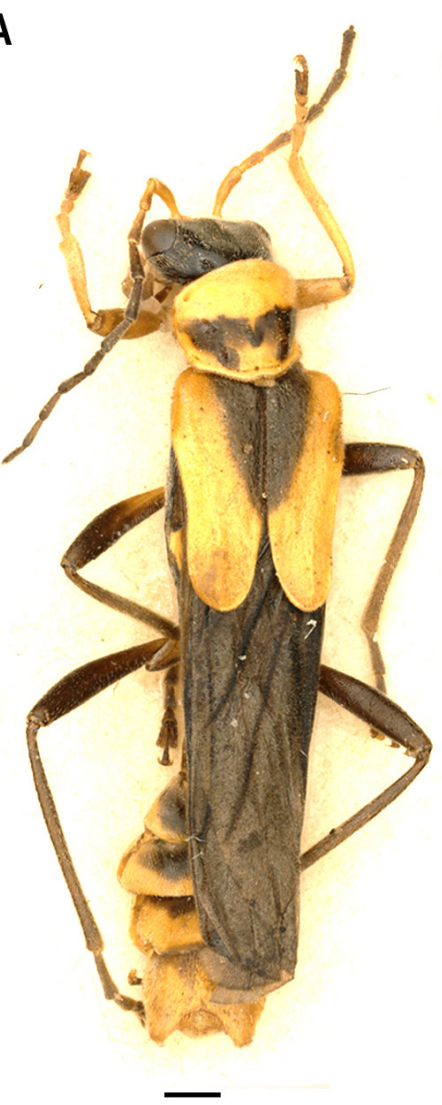

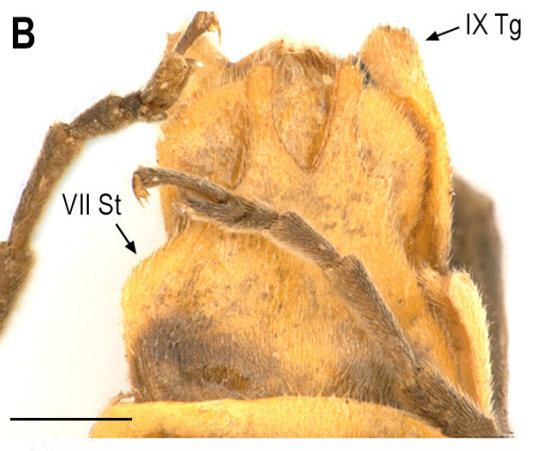

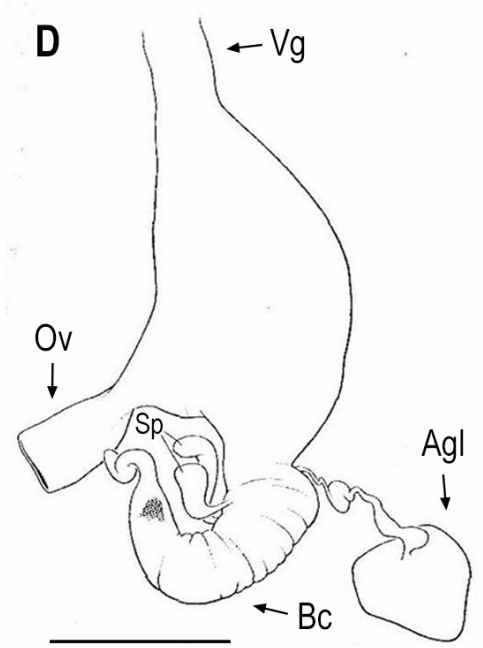

C

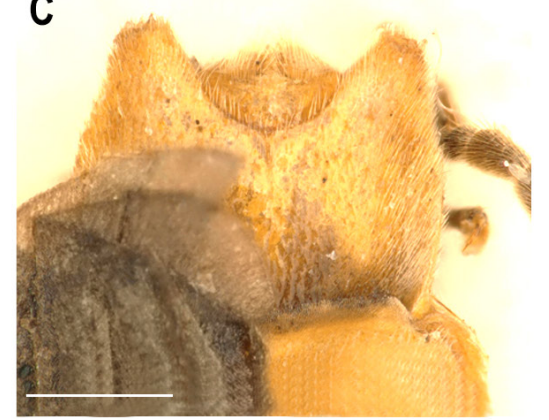

E
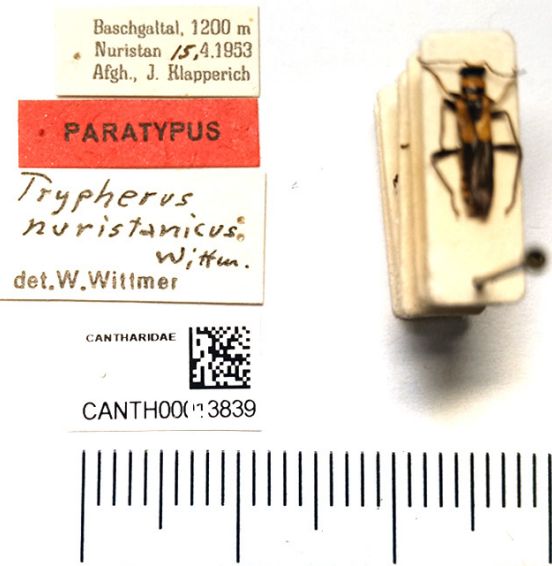

Fig. 7. Trypheridium nuristanicum (Wittmer, 1956) nom. emend., paratype, \& (CANTH00013839, NHMB). A. Habitus, dorsal view. B. Terminal segments, ventral view. C. Terminal segments, dorsal view. D. Genitalia. E. Paratype label. Abbreviations: VII St=sternite VII; IX Tg=tergite IX; $\mathrm{Agl}=$ accessory gland; $\mathrm{Bc}=$ bursa copulatrix; $\mathrm{Ov}=$ oviduct; $\mathrm{Sp}=$ spermatheca; $\mathrm{Vg}=$ vagina. Scale bars: $0.5 \mathrm{~mm}$. Line drawing (D) adapted from Brancucci (1985a). 
Aedeagus. Elongate, weakly sclerotised (Fig. 6G-I); left paramere absent, right paramere and prolongation of tegmen directed posteriorly. Right paramere elongated, ventral face with row of setae, apex flattened, forming rounded lobe; left prolongation of tegmen broad and lamellar, margins sinuous, apex truncate with tip pointing laterally, outer margin with fringe of setae. Median lobe membranous, short, not twisted, opening broad, located apically.

Female (Fig. 7)

Similar to males, except for eyes smaller, less protruding, interocular space 1.4 times larger than widest diameter of eye; antennae shorter, not reaching apex of elytra posteriorly. Sternite VII strongly and variably modified, elongate, projected distally into pair of forked lamellar projections, parallel to slightly divergent, apices rounded, sides of projections angulate at base or near mid length (Fig. 7B); sternite VIII subquadrate, broad and long, partly concealed by sternite VII, lateral margins arched, distal margin with rounded projecting lobe in middle tergite VIII convex, lateral margins slightly arched, distal margin broadly arched, concave, distal angles projected posteriorly, with glandular openings; tergite IX short and broad, distal margins slightly arched, concave (Fig. 7C). Genitalia membranous (Fig. 7D); vagina long and broad; bursa copulatrix elongate, wrinkled, spiralling; spermatheca formed by two tubular projections; accessory gland large, connected by long winding duct to the postero-dorsal part of bursa copulatrix.

\section{Remarks}

Brancucci (1985a) proposed Trypheridium nuristanicus (sic) as a new combination in his description of the neuter genus Trypheridium, of which it is the type species. He omitted to adjust the gender of the species name to agree with Trypheridium. The gender of nuristanicus (an adjective formed from the name of the type locality Nuristan in Afghanistan) is emended to nuristanicum to agree with the neuter Latin suffix -idium of Trypheridium (ICZN 1999, Art. 34.2). When proposing the genus, LeConte (1851)
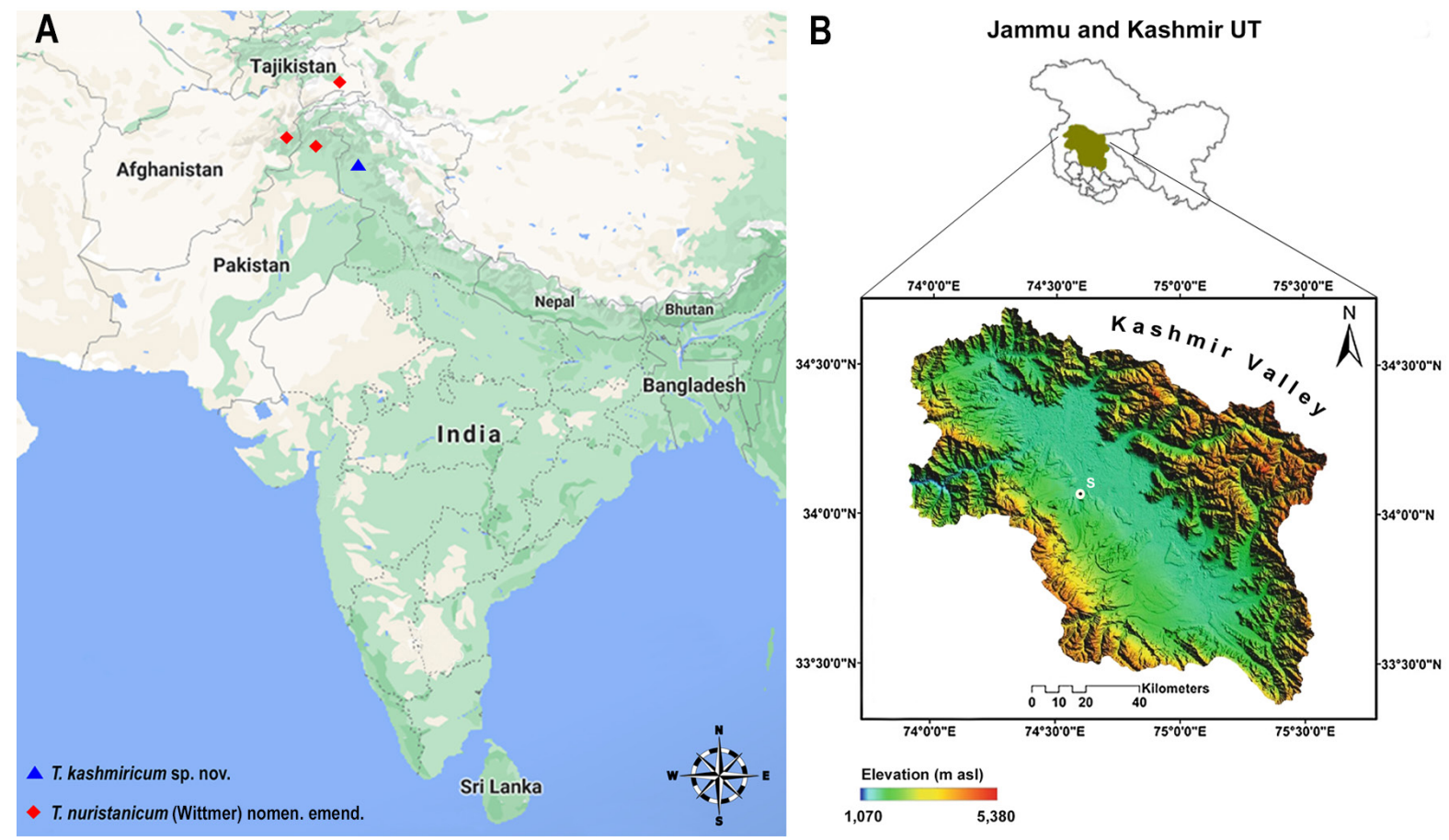

Fig. 8. A. Global distribution of species of Trypheridium Brancucci, 1985. B. Sampling site of Trypheridium kashmiricum sp. nov. 
did not give an etymology for Trypherus, but Gemminger \& Harold (1869) defined the name as meaning "debilis" (week, feeble, fragile, etc). "Trypheridium" is a diminutive, a 'little Trypherus'.

\section{Distribution}

Tajikistan; Afghanistan (Nuristan); Pakistan (Swat) (Fig. 8A).

\section{Discussion}

The two species are very similar by the general morphology and coloration: both exhibit yellow and black regions on the head, a transversal band on the pronotum and a triangular patch on the elytra. However, the species can easily be distinguished by the external morphology of the last tergites and ventrites of the males and females and by the aedeagus. Males of T. nuristanicum have tergite IX with shorter blades, with the apex of the right blade entire, and tergite $\mathrm{X}$ divided into two short lobes, whereas those of T. kashmiricum sp. nov. have the tergite IX with longer and broader blades, with the right blade

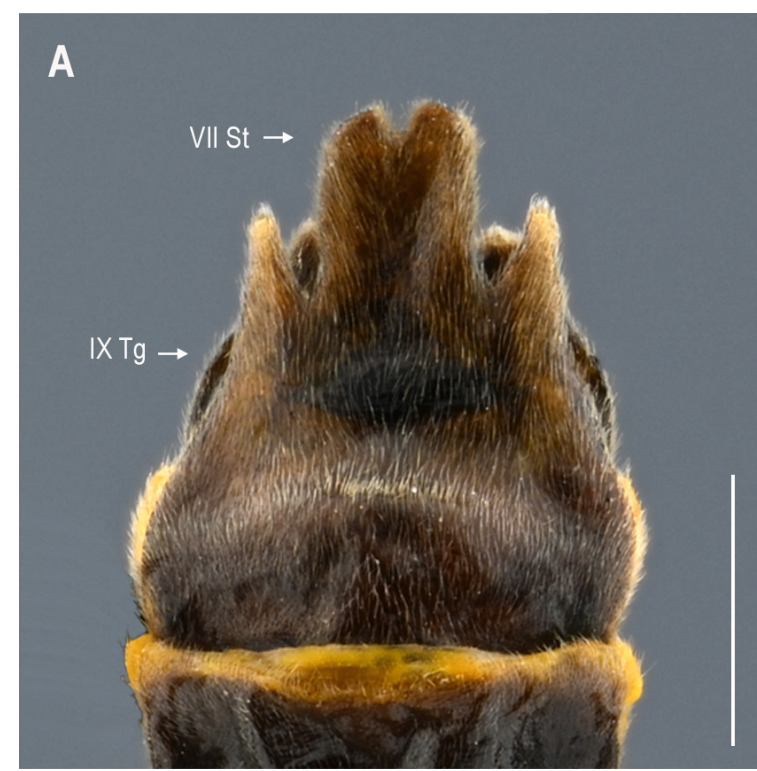

C

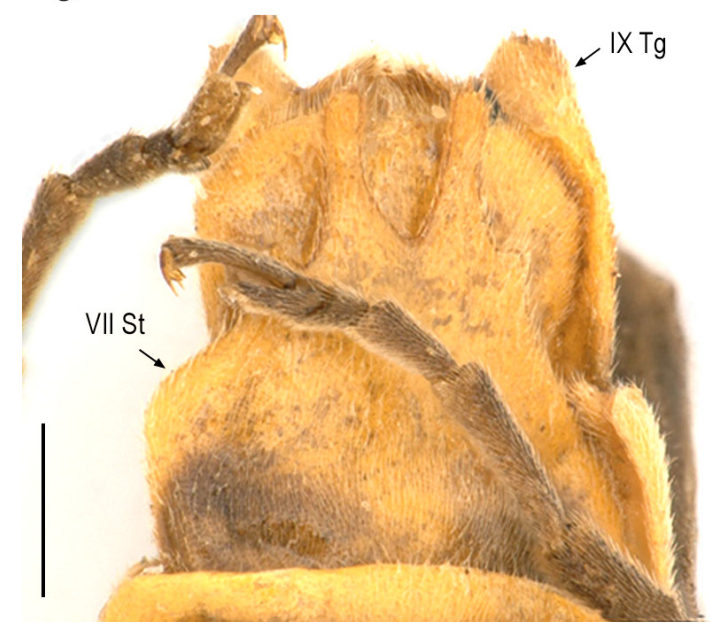

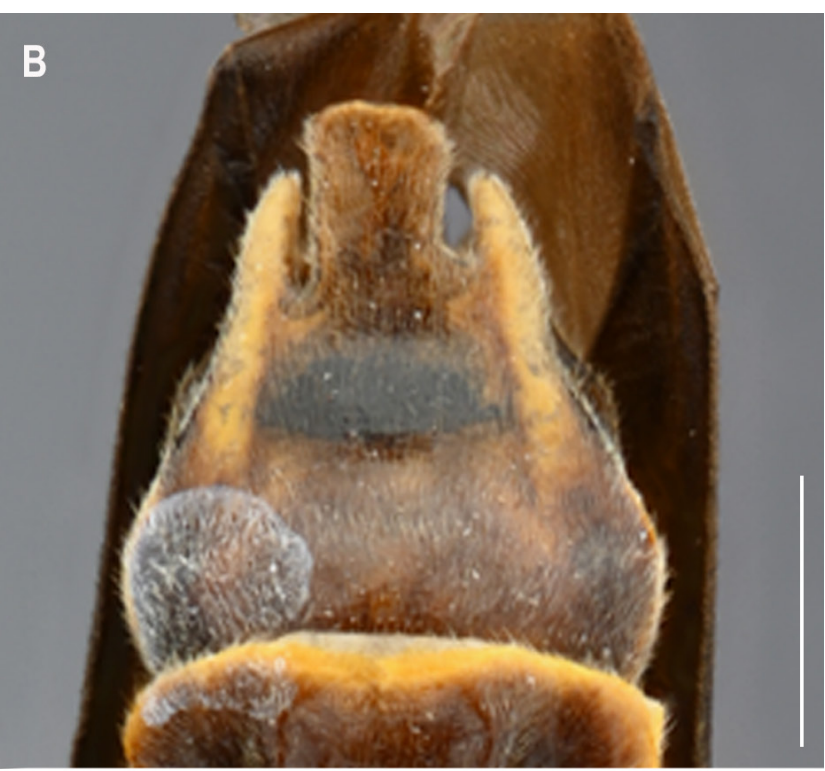

D

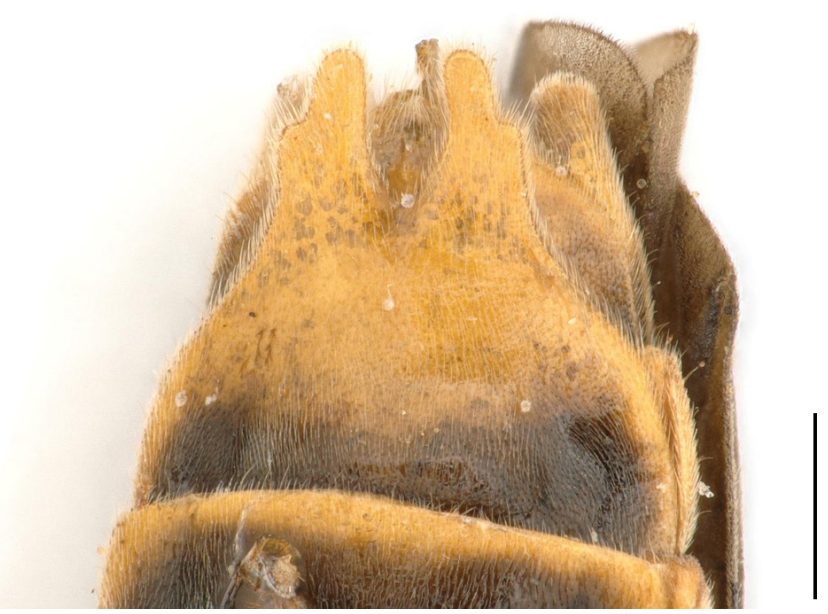

Fig. 9. Variations in the VII ${ }^{\text {th }}$ sternite of species of Trypheridium Brancucci, 1985, $q$ + . A-B. Trypheridium kashmiricum sp. nov. C-D. Trypheridium nuristanicum (Wittmer, 1956). Abbreviations: VII St $=7^{\text {th }}$ sternite; IX Tg $=9^{\text {th }}$ tergite. Scale bars: $0.5 \mathrm{~mm}$. 
divided at the apex, and tergite $\mathrm{X}$ divided into two very long and asymmetrical lobes. The aedeagi of the species are rather similar yet distinguished especially by the shape of the prolongation of the tegmen, which is much wider and abruptly narrowed before the apex in T. nuristanicum, and gradually narrowed in T. kashmiricum sp. nov. The females differ especially in the shape and number of the posterior projections of sternite VII: two projections in T. nuristanicum and three in T. kashmiricum sp. nov. The ventrite VII shows slight to strong differences among the specimens examined (Fig. 9). In T. kashmiricum sp. nov., the length and width of the lateral lobes vary and the distal margin of the median lobe may be truncate or notched (Fig. 9A-B). In T. nuristanicum, however, the differences in the shape, length, width and position of the lateral angles of the distal lobes are more remarkable (Fig. 9C-D). Four different shapes of sternite VII were observed in the four examined female paratypes from the same locality. A thorough examination of the ca 207 type specimens of T. nuristanicum might confirm if that structure is in fact broadly variable or if the type series of T. nuristanicum is composed of more than one species.

The strange morphology of Trypherus nuristanicus had already been pointed out by Magis \& Wittmer (1974) and Brancucci (1980), and Brancucci (1985a) justified the elevation of the genus Trypheridium for that species based on morphological characters and on their widely disjunct distribution. Superficially, Trypheridium is very similar to Trypherus. Both genera are distinguished from the other Palaearctic and Oriental Ichthyurini genera Ichthyurus Westwood, 1848 and Microichthyurus Pic, 1919 especially in the smaller eyes, the antennal insertions separated (not juxtaposed), the pronotum more transverse, not remarkably convex, the males with sternite VIII not split into long prolongations, and tergite IX with well-developed blades directed ventrally and posteriorly (Brancucci 1983, 1985a). Despite the similarity between Trypherus and Trypheridium, according to Brancucci (1985a) the latter differs by their "aberrant" sexual characters, such as the blades of tergite IX in males, which are very elongate, the aedeagus without left paramere (right, according to Brancucci) and the median lobe membranous with a terminal opening (rather than preapical), and sternite VII of females elongate, mostly concealing the sternite VIII (which is uncommon in Trypherus). In addition, the males of species of Trypherus usually have conspicuous modifications on the mid legs, which can be short teeth in the trochanter (one species), the femora slightly to strongly swollen and/or curved (most species) and the tibiae sometimes broader in the apex. The mid legs of both species of Trypheridium are slender, without modifications.

\section{Acknowledgements}

We are grateful to Matthias Borer and Isabelle Zürcher (NHMB) for facilitating us with the images of type material of $T$. nuristanicum. We are also grateful to two anonymous reviewers for their valuable suggestions to improve our manuscript.

\section{References}

Biffi G. 2020. A review and morphological study of Lobetus Kiesenwetter, 1852 (Coleoptera: Cantharidae). Annales Zoologici (Warszawa) 70 (2): 143-179. https://doi.org/10.3161/00034541ANZ2020.70.2.001

Brancucci M. 1980. Morphologie comparée, évolution et systématique des Cantharidae (Insecta: Coleoptera). Entomologica Basiliensia 5: 215-388.

Brancucci M. 1983. La famille des Cantharidae (Coleoptera) sur l'île de Taiwan. 4. La sous-famille des Chauliognathinae. Entomologica Basiliensia 8: 256-309.

Brancucci M. 1985a. Trypheridium n. gen., un nouveau genre pour Trypherus nuristanicus Wittmer (Cantharidae, Coleoptera). Entomologica Basiliensia 10: 245-249. 
Brancucci M. 1985b. Révision du genre Trypherus Leconte (Coleoptera, Cantharidae). Entomologica Basiliensia 10: 251-322.

Chettri N., Shakya B., Thapa R. \& Sharma E. 2008. Status of a protected area system in the Hindu Kush-Himalayas: An analysis of PA coverage. The International Journal of Biodiversity Science and Management 4 (3): 164-178. https://doi.org/10.3843/Biodiv.4.3:4

Delkeskamp K. 1977. Coleopterorum Catalogus Supplementa, Pars 165, Fasc. 1. Col. Cantharidae. Dr W. Junk, The Hague.

Gemminger M. \& Harold B. 1869. Catalogus Coleopterorum hucusque descriptorum synonymicus et systematicus. Tom. VI. Rhipidoceridae, Dascillidae, Malacodermidae, Cleridae, Lymexylonidae, Cupesidae, Ptinidae, Bostrychidae, Cioidae: 1609-1800. Sumptu E.H. Gummi, Monachii. https://doi.org/10.5962/bhl.title.9089

ICZN 1999. International Code of Zoological Nomenclature. Fourth edition. International Trust for Zoological Nomenclature, London. Available from https://www.iczn.org [accessed 19 Jun. 2020].

Kazantsev S.V. 2004. A checklist of Cantharidae (Coleoptera) of the ex-USSR. Russian Entomological Journal 13 (1-2): 23-34.

Kazantsev S.V. 2012. An annoted checklist of Cantharoidea (Coleoptera) of Russia and adjacent territories (to the centenary of the ninth issue of "Beetles of Russia and Western Europe" by Jacobson). Russian Entomological Journal 20 (4): 387-410. https://doi.org/10.15298/rusentj.20.4.05

Kazantsev S.V. \& Brancucci M. 2007. Family Cantharidae Imhoff, 1856. In: Löbl I. \& Smetana A. (eds) Catalogue of Palaearctic Coleoptera, Vol. 4 (Elateroidea, Derodontoidea, Bostrichoidea, Lymexyloidea, Cleroidea, Cucujoidea): 234-298. Apollo Books, Stenstrup.

LeConte J.L. 1851. Synopsis of the Lampyridae of temperate North America. Proceedings of the California Academy of Natural Science 5: 331-347.

Magis N. \& Wittmer W. 1974. Nouvelle répartition des genres de la sous-famille des Chauliognathinae (Coleoptera, Cantharoidea: Cantharidae). Extrait du Bulletin de la Société royale des Sciences de Liège 1-2: 78-95.

Maqbool A., Akbar A.A. \& Wachkoo A.A. 2018. First record of the genus Ficobracon (Hymenoptera: Braconidae) from India, with description of new species. Zootaxa 4379: 421-428.

https://doi.org/10.11646/zootaxa.4379.3.5

Medvedev L. 1964. New species of Ichthyurus (Coleoptera, Cantharidae) from Tajikistan. Doklady Akademii Nauk Tadzhikskoj SSR 7 (6): 44-46. [In Russian.]

Pelletier G. \& Hébert C. 2014. The Cantharidae of Eastern Canada and Northeastern United States. Canadian Journal of Arthropod Identification 25: 1-246. https://doi.org/10.3752/cjai.2014.25

Satô M., Okushima Y., Takahashi N., Li C.-L., Yang Y.-X. \& Hsiao Y. 2014. Checklist of the Cantharidae of Taiwan (Coleoptera: Elateroidea). Collection and Research 27: 43-69.

Searle M. 2013. Colliding continents: a geological exploration of the Himalaya, Karakoram, and Tibet. Oxford University Press, Oxford. https://doi.org/10.1093/oso/9780199653003.001.0001

Wachkoo A.A., Khurshid N., Maqbool A. \& Akbar S.A. 2018. Two first acalyptrate fly (Diptera: Acalyptratae) records from India. Ukrainska Entomofaunistyka 9: 33-36.

Wittmer W. 1956. Afghanistan Ausbeute von Herrn J. Klapperich, 1952/53. Revue suisse de Zoologie 63 (2): 115-161. https://doi.org/10.5962/bhl.part.75446 
Wittmer W. 1972. Synonymische und systematische Notizen sowie neue Taxa in Cantharidae (Col.). Verhandlungen der Naturforschenden Gesellschaft in Basel 82 (1): 105-121.

Manuscript received: 2 February 2021

Manuscript accepted: 21 June 2021

Published on: 20 August 2021

Topic editor: Nesrine Akkari

Section editor: Max Barclay

Desk editor: Kristiaan Hoedemakers

Printed versions of all papers are also deposited in the libraries of the institutes that are members of the EJT consortium: Muséum national d'histoire naturelle, Paris, France; Meise Botanic Garden, Belgium; Royal Museum for Central Africa, Tervuren, Belgium; Royal Belgian Institute of Natural Sciences, Brussels, Belgium; Natural History Museum of Denmark, Copenhagen, Denmark; Naturalis Biodiversity Center, Leiden, the Netherlands; Museo Nacional de Ciencias Naturales-CSIC, Madrid, Spain; Real Jardín Botánico de Madrid CSIC, Spain; Zoological Research Museum Alexander Koenig, Bonn, Germany; National Museum, Prague, Czech Republic. 